\title{
Kritik Hukum Islam Terhadap Undang-Undang Nomor 42 Tahun 2008 Tentang Pemilihan Umum Presiden dan Wakil Presiden Di Indonesia
}

\author{
(ISLAMIC LAW CRITICISM AGAINST LAW NUMBER 42 YEAR 2008 ABOUT \\ GENERAL ELECTION OF PRESIDENT AND VICE PRESIDENT
}

IN INDONESIA)

\author{
Sutisna \\ FAI Universitas Ibn Khaldun (UIKA) Bogor \\ Jl. KH. Sholeh Iskandar Bogor \\ E-mail: sutisna@yahoo.com
}

\begin{abstract}
Islam is a comprehensive religion, which means organizing all aspects of human life. One arranged in Islam is about the election of the head of state. Islam set the global mechanism, so it is possible to modify and adapt with the times. Islam in the contemporary era contributed a model state elections which are applied in the selection of the head of state in Indonesia. The method used is a normative legal studies with a qualitative approach, because the data is qualitative. This study shows that the mechanism of selecting the head of state in Islam is not regulated in detail, so it is possible to modify it.
\end{abstract}

Keyword: Head of State, Elections, President

\begin{abstract}
Abstrak: Islam adalah agama komprehensif, yang berarti mengatur seluruh sendi kehidupan manusia. Salah satu hal yang diatur dalam Islam adalah mengenai pemilihan kepala negara. Islam mengatur secara global mekanismenya sehingga sangat memungkinkan untuk memodifikasi dan menyesuaikan dengan perkembangan zaman. Islam di era kekinian memberikan kontribusi model pemilihan kepala negara yang teraplikasikan dalam pemilihan kepala negara di Indonesia. Metode penelitian yang digunakan adalah normatif legal studies dengan pendekatan kualitatif, karena data-data yang digunakan bersifat kualitatif. Penelitian ini menunjukkan bahwa mekanisme pemilihan kepala negara dalam Islam tidak diatur secara detail, sehingga sangat memungkinkan untuk memodifikasinya.
\end{abstract}

Keyword: Kepala Negara, Pemilu, Presiden

* Diterima tanggal naskah diterima: 20 April 2016, direvisi: 21 Mei 2016, disetujui untuk terbit: 30 Mei 2016. 


\section{Pendahuluan}

Kebutuhan akan adanya pemimpin sudah dirasakan sejak dahulu kala, kepemimpinan pada waktu itu lebih ditekankan pada faktor keturunan geneologis dimana seorang raja akan dipilih karena ada garis keturunan dengan raja tersebut. ${ }^{1}$ Ketika Islam masuk ke Indonesia, kepemimpinan berkembang di beberapa daerah, diantaranya kerajaan Islam Demak di Jawa Tengah, Kerajaan Islam di Gowa di Sulawesi Selatan, kerajaan Islam Kutai Kertanegara di Kalimantan Timur dan sebagainya. Kerajaan-kerajaan tersebut menggunakan gelar sultan, namun pola kepemimpinannya tidak jauh berbeda dengan sistem kerajaan dimana seorang sultan dipilih karena faktor keturunan, yang membedakan antara sistem kerajaan dengan sistem kesultanan hanya pada pedoman hukum yang digunakan.

Memasuki awal abad ke-19 seiring dengan berakhirnya masa kolonialisme di Indonesia, terbentuklah negara Indonesia yang berbentuk republik dimana pola kepemimpinannya beralih dari sistem kerajaan menjadi republik kemudian sistem pemerintahan berubah lagi menjadi presidensial sebagaimana dikatakan oleh Miriam Budihardjo“. Pada masa pra demokrasi terpimpin, yaitu pada bulan November tahun 1945 sampai bulan Juni tahun 1959, kita mengenal badan eksekutif yang terdiri dari presiden dan wakil presiden, sebagai bagian dari badan eksekutif yang tidak dapat diganggu gugat, dan menteri-menteri yang dipimpin oleh seorang perdana menteri yang bekerja atas dasar azas tanggung jawab menteri. Kabinet merupakan kabinet parlementer yang mencerminkan konstalasi politik dalam badan perwakilan rakyat. Hal ini sesuai dengan sistem parlementer yang dianut pada waktu itu, walaupun demikian ada beberapa kabinet yang dipimpin oleh Wakil Presiden Moh. Hatta yang karena itu dinamakan kabinet presidensial."2

Pada masa Orde Lama terbukti ada beberapa penyimpangan yang dilakukan oleh MPR, salah satunya pernah menetapkan Sukarno sebagai presiden seumur hidup. Setelah tumbang Orde Lama maka digantikan dengan Orde Baru. ${ }^{3}$ Selanjutnya pada tahun 1998 setelah runtuh dan berakhirnya rezim Orde Baru terjadilah reformasi, di mana dalam

\footnotetext{
${ }^{1}$ Miriam Budiharjo, Pengantar Ilmu Politik, (Jakarta: Gramedia Pustaka. 2000), hlm. 54. ${ }^{2}$ Ibid.,hlm. 220.

${ }^{3}$ Sjamsuddin, et.al. dalam Pribadi Toto, dkk. Sistem Politik Indonesia,(Jakarta:Penerbit Universitas Terbuka.2007),Cet.ke-2., hlm. 610-611.
} 
perjalanannya telah dipimpin oleh beberapa presiden dan wakilnya. Pada pelaksanaannya sering mengalami perubahan, salah satunya melakukan amandemen terhadap Undang-Undang Dasar 1945 dengan maksud agar tidak terulang lagi penyimpangan dalam praktik kelembagaan negara tersebut meskipun pada awalnya sempat terjadi pro kontra, namun Undang-Undang Dasar 1945 pun telah beberapa kali diamandemen, termasuk perundangundangannya pada undang-undang pemilu presiden dan wakil presiden.

Penduduk Indonesia menurut Biro Pusat Statistik, pada tahun 2012 berjumlah 244.775 .796 jiwa $^{4}$, mayoritas dari penduduknya adalah beragama Islam. Oleh karena itu disini ada persoalan yang menarik untuk dikaji dan diteliti yaitu kenapa umat Islam yang mayoritas di Indonesia namun sistem pemilihan kepala negaranya menggunakan sistem yang tidak sejalan dengan nilai-nilai Islam. Tentu saja ada beberapa pertimbangan kenapa hal ini terjadi. Bila kita runut ke dalam sistem sosial keagamaan di Indonesia, maka kita akan mendapatkan beberapa hasil penelitian, diantaranya penelitian Clifford Geertz yang membagi Islam Indonesia menjadi; Islam Abangan, santri dan priyayi. $^{5}$

Indonesia pasca reformasi memiliki beberapa peraturan terkait dengan kepemimpinan. Salah satu dari peraturan tersebut adalah Undang-undang tentang Pemilihan Umum Presiden dan Wakil Presiden yaitu Undang-Undang Pemilu No. 23 Tahun 2003 dan kemudian mengalami perubahan ke undangundang berikutnya yaitu disempurnakan dengan keluarnya Undang-Undang No. 42 Tahun 2008, tentang Pemilihan Presiden dan Wakil Presiden di Indonesia. Ada beberapa bab, pasal, ayat dan butir dalam Undang-undang tentang Pemilihan Umum Presiden dan Wakil Presiden yaitu Undang-Undang Pemilu No. 23 Tahun 2003 dan kemudian disempurnakan dengan Undang-Undang No. 42 Tahun 2008, tentang Pemilihan Presiden dan Wakil Presiden di Indonesia yang cukup menarik untuk dijadikan bahan penelitian mengingat substansi persoalan yang terkandung dalam pasal-pasal tersebut memiliki persinggungan yang cukup penting dengan prinsip-prinsip ajaran Islam mengenai pemilihan kepala negara dalam Islam. ${ }^{6}$

\footnotetext{
${ }^{4}$ Badan Pusat Statistik.Statistik Indonesia: Statistical Yearbook of Indonesia 2012, (Jakarta:

Badan Pusat Statistik. 2012). Versi Online.Diakses melalui http://www.bps.go.id/ hasil_publikasi/si_2012/index3.php?pub=Statistik\%20Indonesia\%202012, 5 Agustus 2014.

${ }^{5}$ Clifford Geertz. The Religion of Java, (Chicago: Chicago Press. 1976).

${ }^{6}$ Abu Tamrin, "Urgensi Pemilu Presiden dan Wakil Presiden Secara Langsung di Era Reformasi" Jurnal Cita Hukum [Online], Volume 1 Number 2 (2 December 2013), h. 187-194.
} 


\section{Mekanisme Pemilihan Kepala Negara dalam Islam}

Istilah kepemimpinan dalam hukum Islam ada beberapa yang digunakan, yaitu khilafah, imamah, imarah, sultan, mulk dan ri'asah. Kata khilafah berasal dari kata khalafa-yakhlifu-khalfun yang berarti al-'aud atau al-balad yakni mengganti, yang pada mulanya berarti belakang. ${ }^{7}$

Adapun pelakunya yaitu orang yang mengganti disebut khalifah dengan bentuk jamak khulafa' yang berarti wakil, pengganti dan penguasa. Kata khalifah sering diartikan sebagai pengganti, karena orang yang menggantikan datang sesudah orang yang digantikan dan ia menempati tempat dan kedudukan orang tersebut. Khalifah juga bisa berarti seseorang yang diberi wewenang untuk bertindak dan berbuat sesuai dengan ketentuanketentuan orang memberi wewenang. Menurut Al-Ragib al-Asfahani arti "menggantikan yang lain" yang dikandung kata khalifah berarti melaksanakan sesuatu atas nama yang digantikan, baik orang yang digantikannya itu bersamanya atau tidak. ${ }^{8}$

Syarat untuk menjadi calon kepala Negara Islam seperti yang disyaratkan oleh ahli hukum Islam yaitu Imam Al-Mawardi dalam Al-Ahkam al-Sulthaniyahsebagai berikut: ${ }^{9}$

1. Keseimbangan (al-adalah) yang memenuhi semua kriteria.

2. Mempunyai ilmu pengetahuan yang membuatnya dapat melakukan ijtihad untuk menghadapi kejadian-kejadian yang timbul dan untuk membuat kebijakan hukum.

3. Pancaindranya lengkap dan sehat dari pendengaran, penglihatan, lidah, dan sebagainya- sehingga ia dapat menangkap dengan benar dan tepat apa yang ditangkap oleh indranya itu.

4. Tidak ada kekurangan pada anggota tubuhnya yang menghalanginya untuk bergerak dan cepat bangun.

5. Visi pemikirannya baik sehingga ia dapat menciptakan kebijakan bagi kepentingan rakyat dan mewujudkan kemaslahatan mereka.

6. Mempunyai keberanian dan sifat menjaga rakyat, yang membuatnya mempertahankan rakyatnya dan memerangi musuh.

7Tbnu Manzhur, Lisaan al-Arab, (Kairo: Daarul Ma'arif. T.th.), hlm. 1235.

${ }^{8}$ Al-Raghib al-Asfahani, Mu'jam Mufradat li Alfazh al-Qur'an, (Beirut-Libanon: Dar alKutub al-'Ilmiyah. 2004), hlm. 174-175.

${ }^{9} \mathrm{Abu}$ al-Hasan Ali bin Muhammad bin Habib al-Basri Al-Baghdadi Al-Mawardi alSyafi'i. Al-Ahkam al-Sulthaniyyah wa al-Wilayah al-Diniyyah,(Mesir: Dar al-Fikr. 1960 M./ 1380 H.), Cet. ke-1, hlm. 6. 
7. Ia mempunyai nasab dari suku Quraisy karena adanya nash tentang hal itu dan telah terwujudnya ijma ulama tentang masalah itu.

Mendengar itu mereka mengubah posisi dan selanjutnya berusaha melakukan negosiasi dengan menawarkan, "Dari kami ada pemimpin tersendiri dan dari kalian ada pemimpin tersendiri," karena mereka membenarkan hadits tadi dan menerimanya. Akhirnya, mereka dengan senang hati menerima tawaran terakhir yang diberikan Abu Bakar r.a saat ia berkata kepada mereka, "Dari kami para pemimpin dan dari kalian para menteri. "Rasulullah Saw. Bersabda, "Angkatlah individu dari suku Quraisy dan jangan kalian langkahi mendahului mereka Nash yang telah diterima ini tidak mengandung kesamaran yang perlu dipertanyakan, juga tidak ada pendapat yang menentangnya. ${ }^{10}$

Menurut ulama lain persyaratan bagi yang hendak memegang jabatan kepala negara Islam lebih banyak lagi persyaratannya yaitu:

1. Islam. Kepala negara Islam harus beragama Islam. Orang kafir sehebat apapun tidak dibenarkan memegang jabatan penting ini secara mutlak.

2. Dewasa, Aqil baligh. Mencapai usia dewasa (baligh) sebagaimana diketahui menjadi prasyarat beban agama (taklif).

3. Berakal. Akal juga perangkat taklif oleh sebab itu tidak dibenarkan mengangkat orang yang tidak sempurna akalnya (gila) menjadi pemimpin karena Allah apabila mengambil apa yang dia berikan secara kodrati- berarti menggugurkan apa yang dia wajibkan.

4. Merdeka. Hamba sahaya, atau hamba yang akan dibebaskan bersyarat tidak dapat memegang kepemimpinan negara karena mereka terikat dengan pekerjaan dan hak orang lain.

5. Laki-laki. Para ulama salaf dan juga khalaf telah sepakat bahwasanya tidak dibenarkan perempuan memegang kepemimpinan negara Islam, karena sabda Rasulullah Saw. "Tidak akan beruntung suatu kaum yang menyerahkan urusan kepemimpinan mereka kepada seorang perempuan."

6. 'Adalah (kelayakan moral). Yang dimaksud dengan adil atau layak moral bagi calon kepala negara Islam tidak berarti ia terpelihara dari kesalahan ucapan, perbuatan dan sikapnya.

7. Mempunyai kemampuan. Ibnu Khaldun berkata jika kepala negara tegas dalam menegakkan hukum pidana dan mendobrak peperangan,

${ }^{10}$ Ibid. hlm. 17-19. 
memahami politik hukum dan perang, mampu mengarahkan manusia, mengetahui liku-liku persekongkolan, kuat menghadapi beratnya politik, maka dengan demikian ia mampu melindungi agama, memerangi musuh, menegakan hukum, dan mengurus kepentingan. ${ }^{11}$

8. Berpengetahuan. Para ulama membuat persyaratan hendaknya kepala negara Islam memiliki ilmu pengetahuan.

9. Tidak meminta Imarah. Islam melarang seseorang meminta jabatan kepemimpinan sebab dengan demikian merupakan pengakuan diri suci dan ini tercela. Allah berfirman: "Maka janganlah kamu mengatakan dirimu suci."(QS Anajm: 32).

10. Berdiam di dalam negeri. Khalifah harus warga negara Islam yang bertempat tinggal didalam negeri dan hidup bersama warganya dan ikut merasakan apa yang mereka hadapi. Dengan demikian calon khalifah tidak dibenarkan orang yang hidup di negeri kafir, meskipun ia berakhlak mulia, memiliki sifat-sifat yang baik.

11. Sehat Indra dan Anggota Badan. Maksud persyaratan ini adalah sehat indra dan anggota badan yang tidak menyebabkan gangguan serius dalam kepemimpinan seperti tidak mempunyai daya penglihatan, wicara, pendengaran, dan lain-lain yang memberi pengaruh pada penalaran dan analisa.

12. Keturunan Quraisy. Khalifah disyaratkan dari keturunan, yakni nasab berakhir Fihr bin Malik dan dikatakan oleh sebahagian pendapat pada Nadhar bin kinanah. Persyaratan ini dipandang secara berbeda oleh para ulama dan menjadi perdebatan sengit di kalangan mereka baik di masa lalu maupun masa mu'takhir.

\section{Pemilihan Kepala Negara di Indonesia dan Perkembangannya}

Teori Hukum Tata Negara (HTN) berlandaskan pada prinsip negara hukum (rechtstaat) seperti Indonesia, studi tentang pengangkatan kepala negara melalui pendekatan yuridis menjadi sebuah keharusan, telah banyak diintrodusir oleh para pakar hukum tata negara. ${ }^{12}$ Salah satu asas penting dari negara hukum adalah asas legalitas yang menekankan bahwa substansi dari

${ }^{11} \mathrm{Ibnu}$ Khaldun, Muqaddimah ..., hlm. 66.

${ }^{12}$ Abraham Amos, Sistem Ketata Negaraan Indonesia, (Jakarta: Rajawali Pers. 2007), hlm. $12-40$. 
asas legalitas adalah bahwa setiap aktivitas badan/pejabat administrasi negara harus berdasarkan undang-undang. ${ }^{13}$ Pendekatan yuridis yang penulis kemukakan di sini adalah pendekatan melalui peraturan perundangundangan yang berlaku di Indonesia, antara lain; Undang-Undang dasar 1945 Pasca revolusi ${ }^{14}$ hingga Pasca reformasi ${ }^{15}$, Undang-Undang Tentang Pemilu, ${ }^{16}$ dan Undang-Undang lain yang berkaitan dengan proses pengangkatan kepala negara. ${ }^{17}$

Mekanisme pengangkatan presiden dan wakilnya di Indonesia didasarkan kepada Undang-Undang Dasar 1945, tepatnya pada era Demokrasi liberal tahun 1945-1949. Pasca ditetapkannya konstitusi pertama negara Republik pada tanggal 18 Agustus 1945, yakni sehari setelah dinyatakan proklamasi kemerdekaan Indonesia, secara yuridis-konstitusional (HTN) Undang-Undang Dasar tersebut dikenal dengan nama UndangUndang Dasar 1945. Konstitusi ini dapat dikatakan sebagai "revolusi grondwe't. ${ }^{18}$ Konstitusi tertulis yang menjadi sandaran Hukum Ketatanegaraan (HTN) Indonesia secara konstitusional terdapat lima bentuk konstitusi yakni: Periode antara Agustus 1945 yang berlaku sampai 27 Desember 1949, Konstitusi RIS berlaku pada tahun 1949-1950, UUDS yang berlaku pada tahun 1950-1959, UUD 1945 Pasca Dekrit presiden. Berlaku pada tahun 19591998, UUD 1945 Pascareformasi periode 1998 sampai sekarang (sebelum maupun sesudah amandemen). ${ }^{19}$

Pengangkatan presiden Republik Indonesia pada era kemerdekaan awal secara konstitusional diatur dalam Undang-Undang Dasar 1945, pasal 6 dengan ketentuan sebagai berikut:

(1) presiden ialah orang Indonesia asli.

(2) presiden dan wakil presiden dipilih oleh Majelis Permusyawaratan Rakyat dengan suara terbanyak. ${ }^{20}$

${ }^{13} \mathrm{Ni}^{\prime}$ matul Huda, Hukum Tata Negara ..., hlm.78.

${ }^{14}$ UUD 1945 yang di tetapkan pada tanggal 18 Agustus 1945 oleh PPKI, dan UUD 1945 pasca Dekrit Presiden 5 Juli 1959.

15UUD 1945 setelah amademen, I, II, III dan ke IV.

16UU No. 12 Tahun 2003 tentang Pemilihan Umum. Lihat UU No. 10 Tahun 2008 Tentang Pemilu Anggota DPR, DPD, dan DPRD.

${ }^{17}$ UU No. 42 Tahun 2008 tentang Pemilihan Umum Presiden dan Wakil Presiden.

${ }^{18}$ Ismail Suny, Pergeseran Kekuasaan Eksekutif, (Jakarta, Aksara Baru, 1983), h. 13.

${ }^{19} \mathrm{Ni}$ 'matul Huda, Hukum Tata Negara, (Jakarta, Rajagrafindo, 2010), h .124.

${ }^{20}$ Moh. Mahfud MD. Demokrasi dan Konstitusi Indonesia, (Jakarta. Rineka Cipta 2003), hal.195. 
Ketentuan peraturan perundang-undangan di atas menunjukkan bahwa untuk pertama kali secara konstitusional mekanisme pengangkatan kepala negara dilakukan secara demokrasi (representative), yakni melalui perwakilan. Dalam hal ini seluruh rakyat Indonesia baik secara yuridis ataupun secara politis telah mendelegasikan hak konstitusionalnya kepada para wakil rakyat yang ada di lembaga permusyawaratan rakyat. Sehubungan lembaga tersebut secara organik belum eksis dikarenakan berbagai kondisi, maka presiden dan wakil presiden Indonesia dipilih dan ditetapkan oleh Panitia Persiapan Kemerdekaan Indonesia (PPKI). ${ }^{21}$

Peraturan pemilihan Presiden pada masa Orde baru tahun 1966-1997. Pasca sistem demokrasi terpimpin jatuh, maka digantikan oleh sistem politik baru yang lebih terkenal dengan sistem demokrasi Pancasila. Sistem baru ini lahir berbarengan dengan munculnya rezim Orde Baru di bawah pimpinan Jenderal Soeharto. Terlepas dari kontroversialnya sistem demokrasi yang dibangun Soekarno era 1945-1965, eksistensi Undang-Undang Dasar 1945 pasca Dekrit presiden ini, selain telah meletakan dasar-dasar konstitusi, juga telah mampu menyelenggarakan 9 kali pemilu (1971; 1977; 1982; 1987; 1992; 1997; 1999, 004 dan 2009) untuk memilih Anggota Dewan Legislatif atau wakil rakyat, yang kemudian diteruskan dengan pemilihan presiden dan wakil presiden oleh Majelis Permusyawaratan Rakyat (MPR) hasil pemilu..$^{22}$ Proses pelaksanaan pemilu era orde baru layak untuk dicermati, mengingat pada era ini meskipun setiap pemilu sejak tahun 1972-1997 diikuti oleh banyak partai politik sebagai peserta pemilu.

Pemilu dilakukan setiap lima tahun sekali untuk memilih anggota legislatif dan Presiden serta Wakil Presiden. Masyarakat bebas memilih partai yang disukainya yang ikut dalam pemilu. Pada masa itu masyarakat hanyalah memilih partai. Anggota legislatif ditentukan oleh pemerintah yang berkuasa (Soeharto) berdasarkan daftar yang diajukan oleh panitia yang ditunjuk oleh presiden. Pada masa itu, panitia yang bertugas mencari calon anggota legislatif ialah militer di setiap daerah. Daftar nama calon itu kemudian diserahkan kepada presiden. Biasanya setiap masa pemilihan, presiden selalu menyeleksi anggota legislatif tersebut.

${ }^{21} \mathrm{Ni}^{\prime}$ matul Huda. Hukum Tata Negara Indonesia, Ibid., hal 110.

${ }^{22}$ Gatara; Ilmu Politik...... hlm 214 


\section{Analisis Undang-Undang No. 42 Tahun 2008 tentang Pemilihan Presiden dan Wakil Presiden}

Hukum Islam sebagai hukum yang datang dari Allah ta'ala memiliki nilai-nilai Ilahiyah yang bersumber dari Alquran dan al-Sunnah. Nilai-nilai Ilahiyah tersebut tercermin dari sifatnya yang selaras dengan nilai-nilai kemanusiaan. Sehingga hukum Islam adalah hukum yang diciptakan oleh Allah ta'ala sebagai Sang Pencipta manusia itu sendiri. Sebagai Pencipta manusia, Allah ta'ala pasti mengetahui sesuatu yang baik bagi para ciptaanNya tersebut. Hal ini yang membedakannya dengan hukum-hukum yang dibuat oleh manusia. Jika hukum-hukum yang dibuat oleh manusia seringkali adanya amandemen dan revisi, maka hukum-hukum Allah akan tetap abadi selamanya hingga akhir dunia ini.

Undang-undang No. 42 Tahun 2008 tentang Pemilihan Presiden dan Wakil Presiden di Indonesia adalah hukum yang dibuat oleh manusia, tapi manusia yang membuatnya adalah manusia yang beragama, sehingga apa yang mereka lakukan tidak akan terlepas dari bingkai ajaran agama. Untuk membuktikan tesis itu, penulis menganalisis relevansi syarat-syarat pencalonan presiden dan wakil presiden yang terdapat dalam Pasal 5 Undang-undang No. 42 Tahun 2008 tentang Pemilihan Presiden dan Wakil Presiden di Indonesia dengan hukum Islam. Syarat-syarat tersebut adalah sebagai berikut;

Syarat pertama, bertakwa kepada Tuhan Yang Maha Esa.Ini syarat yang sangat relevan dengan ajaran Islam. Bertakwa kepada Tuhan Yang Maha Esa. Persyaratan seorang calon kepala negara yang disebutkan pada Pasal 5 ayat adalah bahwa ia haruslah seorang yang bertakwa kepada Tuhan Yang maha Esa. Oleh karena itu sudah selayaknya bagi seluruh masyarakat Indonesia untuk menjadikan kepala negara di Indonesia adalah seorang muslim. Syarat ini tidak bisa ditawar lagi, hanya saja perlu ditegaskan lebih spesifik dalam ayat ini. Jangan sampai ia memiliki tafsir ganda yang menganggap bolehnya pemimpin selain muslim. Padahal sebagaimana diketahui bahwa syarat ini hanya ada pada masyarakat muslim yang beriman kepada Tuhan Yang Maha Esa. Allah SWT. berfirman:

"Wahai umat manusia sesungguhnya kamu kami jadikan terdiri dari pria dan wanita, dan kami ciptakan kamu berkaum dan berbangsa untuk saling berkenalan bahwa 
orang yang paling mulia dlam pandangan Allah yaitu yang paling bertaqwa. Sungguh Allah maha mengetahui, maha teliti". (QS. Al-Hujurat [49]:13). ${ }^{23}$

Ketakwaan merupakan unsur sangat penting dalam ajaran Islam yang harus melekat pada diri seorang pemimpin. Islam tidak menomorsatukan garis ketrurunan; tapi mengedepankan ketakwaan. Hadits-hadits yang menyatakan bahwa pemimpin harus dari suku Quraisy pun telah dipahami berbeda-beda oleh para ulama. Kaum Khawarij, Jumhur kalangan Mu'tazilah, sebagian Murji'ah, Qadhi Abu Bakar Al-Bâqilâni, sebagian kelompok Ghulat al-Imâmiyyah, Ibnu Khaldun, Imam Ibnul Hajar Al-'Asqalani, dan para ulama kontemporer berpendapat bahwa nasab Quraisy tergolong syarat afdhaliyyah bukan termasuk syarat in'iqad. ${ }^{24}$

Begitu pula hadits yang diriwayatkan oleh Ath-Thabarani dalam $\mathrm{Al}$ Mu'jam As-Shaghîr dan Al-Ausath dari Tsanban berkata: Rasulullah Saw. bersabda: "Peganglah janji setia kepada Quraisy selama mereka setia (tidak khianat) memimpin kalian. Jika mereka tidak melakukan (khianat dalam memimpin umat) maka angkatlah pedang kalian di atas pundak kalian dan musnahkanlah pemimpin-pemimpin (Quraisy) itu." 25

Syarat kedua, warga Negara Indonesia sejak kelahirannya dan tidak pernah menerima kewarganegaraan lain karena kehendaknya sendiri. Syarat ini sangat Islami, karena dalam ajaran Islam kesetiaan itu merupakan salah satu unsur yang sangat penting dalam hal kepemimpinan dan salah satu unsur atau indikator dari kesetiaan adalah tidak berubahnya kewarganegaraan seseorang. Jika seseorang berganti kewarganegaraan, maka kesetiaan akan diragukan. Hadits-hadit yang menjelaskan bahwa pemimpin harus dari Quraisy, menurut penulis sesungguhnya semangat ajarannya adalah bahwa pemimpin harus warga pribumi dan harus dari kelompok yang memiliki kapasitas yang pada saat itu di Saudi Arabia adalah suku Quraisy.

Syarat ketiga, tidak pernah mengkhianati negara, serta tidak pernah melakukan tindak pidana korupsi dan tindak pidana berat lainnya. Seorang kepala negara haruslah seorang yang memiliki loyalitas tinggi kepada negara. istilah lain dari loyalitas ini adalah ia memiliki sikap nasionalisme yang tinggi, yaitu cinta kepada tanah air dan bangsa Indonesia. Selain itu ia juga seorang yang bersih dari tindak pidana korupsi dan tindak pidana lainnya yang

\footnotetext{
${ }^{23}$ Soenarjodkk., Al-Qur'an dan ..., hlm. 847.

${ }^{24}$ Al-Amidi, Al-Fashl fil Milal wal Ahwâ wan Nihal, Juz 4, hlm. 89

${ }^{25}$ Al-Haitsami, Majmau' az Zawâid, Juz 5, hlm. 228.
} 
dianggap kejahatan yang berat. Seseorang yang terbukti melakukan tindak pidana berat tersebut maka ia tidak diperbolehkan menjadi kepala negara.

Syariah Islam telah menetapkan syarat-syarat yang harus ada bagi calon kepala negara atau khalifah. Syarat-syarat tersebut ada yang disebutkan secara qath'i di dalam Alquran dan al-Sunnah, namun ada pula yang merupaka ijtihad para ulama berdasarkan kedua sumber hukum Islam tersebut. Buku Al Imamatul Udzma 'Inda Ahlil Sunnati wal Jama'ah karya Syekh Ad Dumaijiy menjelaskan tentang syurutul Imam, atau syarat-syarat seorang Imam (kepala negara/khalifah), yakni: 1.Islam, 2. Baligh, 3. Berakal, 4. Merdeka, 5. Laki-Laki, 6. Berilmu, 7. Adil, 8. Mampu Jiwanya, 9. Mampu Fisiknya, 10. Tidak ada penghalang untuk menjadi Khalifah, dan yang terakhir atau ke-11. Quraisy. Sementara itu, Syekh An-Nabhany dalam Kitab Muqaddimah Dustur menjelaskan bahwa syarat kepala negara adalah, 1.Lakilaki, 2. Muslim, 3. Merdeka, 4. Baligh, 5. Berakal, 6. Adil, dan yang ke-7. Mampu.

Imam Al Mawardi dalam bukunya $A l$ Ahkamu $A l$ Sulthaniyah menjelaskan bahwa ada tujuh syarat yang harus dimiliki oleh orang yang berhak dicalonkan sebagai Kepala Negara (Khalifah), yakni: 1. Al-Adalah atau adil dalam semua kriteria, 2. Berilmu, untuk ijtihad, 3. Sehat (panca indra lengkap), 4. Tidak cacat yang menghalangi dari bergerak dan cepat dalam bertindak, 5. Memiliki visi yang baik, 6. Berani dan menjaga rakyat, 7 . Quraisy.

Syarat kelima, "bertempat tinggal di wilayah Negara Kesatuan Republik Indonesia. Syarat ini diaksudkan supaya kepala Negara mampu melaksanakan tugasnya dengan sebaik-baiknya, sehingga terjadi kepemimpinan yang efektif dan efisien, tidak melakukan kemubadzdziran atau pemborosan karena kemubadzdziran sangat ditentang oleh Islam sebagaimana ditegaskan dalam surat Al-Isra ayat 27 yang artinya: "Sesungguhnya pemboros-pemboros itu adalah saudara-saudara syaitan dan syaitan itu adalah sangat ingkar kepada Tuhannya". (QS. Al-Isra, 17: 27). ${ }^{26}$ Dalam ajaran Islam, Khalifah harus warga negara Islam yang bertempat tinggal didalam negeri dan hidup bersama warganya dan ikut merasakan apa yang mereka hadapi dengan demikian calon khalifah tidak dibenarkan orang yang hidup dinegeri kafir meskipun ia berahlak mulia, memiliki sifat-sifat yang baik. Sebab hijrah kedarul Islam adalah wajib dan dengan hijrah jumlah

${ }^{26}$ Ibid., hlm. 428. 
warga muslim bertambah banyak. Serta menambah jumlah pembela kaum muslimin. Hal ini dijelaskan dalam (QS: Al-Anfal : [8]: 72).

Syarat keenam, "Telah melaporkan kekayaannya kepada instansi yang berwenang memeriksa laporan kekayaan penyelenggara Negara". Semangat dari syarat ini adalah untuk mencegah kepala Negara dan wakilnya dari melakukan tidakan korupsi untuk memperkaya diri, keluarga, dan kelompoknya dengan cara mengikuti kehendak hawa nafsu, sebagaiana dilarang dalam QS.Shaad: $26 .{ }^{27}$

Syarat ketujuh, "tidak sedang memiliki tanggungan utang secara perseorangan dan/atau secara badan hukum yang menjadi tanggung jawabnya yang merugikan keuangan Negara". Syarat ini sangat penting demi menjaga kelancaran pemerintahan. Apabila seorang presiden dibebani oleh utang pribadi atau kelompok, maka dia tidak akan bisa konsentrasi dalam menjalankan tugasnya, bahkan bisa juga beban utang dia pikul akan menjadi salah satu pemicu untuk melakukantindkan korupsi. Korupsi sangat bertentangan dengan ajaran karena korupsi bisa menyengsarakan masyarakat luas, padahal, Islam sangat mengutamakan kepentingan masyarakat luas daripada kepentingan pribadi atau kelompok. Seorang pemimpin harus amanah sebagaimana sebagaimana firman Allah ta'ala:

"Sesungguhnya Allah menyuruh kamu menyampaikan amanat kepada yang berhak menerimanya dan menyuruh kamu, apabila menetapkan hukum diantara manusia, supaya menetapkan dengan adil. Sesungguhnya Allah memberi pengajaran yang sebaik-baiknya kepadamu. Sesungguhnya Allah Maha Mendengar lagi Maha Melihat". (Q.S. Al-Nisa [4]: 58).28

Syarat kedelapan "tidak sedang dinyatakan pailit berdasarkan putusan pengadilan". Seseorang yang dinyatakan pailit oleh putusan pengadilan berarti dia sedang berada dalam kondisi kesulitan dalam mengelola kepentingan pribadinya. Jika seseorng sudah tidak mampu mengatur dirinya sendiri, maka bagaimana mungkin dia akan bisa mengatur Negara yang demikian kompleks. Dalam ajaran Islam orang yang tengah pailit (jatuh bangkrut/gharimiin) bukanharus dibebani dengan cara dijaikan pemimpin; tapi harus ditolong dengan cara diberikan bagian dari harta zakat, sebagaimana firman Allah dalam QS. Al-Taubah: 60.29

\footnotetext{
${ }^{27}$ Ibid., hlm. 736 .

${ }^{28}$ Ibid., ...,hlm. 128.

${ }^{29}$ Ibid., ...,hlm. 288.
} 
Syarat kesembilan "tidak pernah melakukan perbuatan tercela." Dalam ajaran Islam, seorang pemimpin haruslah orang yang berakhlak mulia yang tidak pernah melakukan perbuatan tercela. Yang dimaksud dengan adil atau layak moral bagi calon kepala negara Islam tidak berarti ia terpelihara dari kesalahan ucapan, perbuatan dan sikapnya. Sebab sifat ma'syum hanya dimiliki para rasul, yang memang dapat perlindungan istimewa dari Allah dari perbuatan dan maksiat. Sedangkan muslim biasa tidak tertutup kemungkinan melakukan kesalahan dan dosa-dosa kecil tidak menggugurkan kelayakan moralnya melainkan cukup dengan istigfar dari perbuatan salah dan dosa kecil yang disadari dengan tetap berniat untuk memperbaiki diri. “Rasulullah Saw. Bersabda: “Demi Allah yang jiwaku ada ditangannya, seandainya kalian tidak melakukan dosa, niscaya Allah melenyapkan kalian dan mendatangkan suatu kaum yang berdosa, lalu mereka memohon ampunan lalu Allahpun mengampuni mereka. (Muslim)." ${ }^{\prime 30}$

Syarat kesepuluh, "terdaftar sebagai pemilih". Warga negara yang terdaftar sebagai pemilih merupakan salah satu indikasi bahwa dia adalah seorang warga negara yang baik, yang aktif, dan disiplin; dan sebaliknya.Islam telah memerinthkan setiap Muslim untuk menjadi orang yang taat kepada Allah dan juga sebagai warga Negara taat terhadap Negara. Allah berfirman:

"Hai orang-orang yang beriman, taatilah Allah dan taatilah Rasul (Nya), dan ulil amri di antara kamu. Kemudian jika kamu berlainan pendapat tentang sesuatu, maka kembalikanlah ia kepada Allah (Alquran) dan Rasul (sunnahnya), jika kamu benar-benar beriman kepada Allah dan hari kemudian. Yang demikian itu lebih utama (bagimu) dan lebih baik akibatnya". (QS. Al-Nisa [4] : 59). ${ }^{31}$

Syarat kesebelas "memiliki nomor pokok wajib pajak (NPWP) dan telah melaksanakan kewajiban membayar pajak selama 5 (lima) tahun terakhir yang dibuktikan dengan Surat Pemberitahuan Tahunan Pajak Penghasilan Wajib Pajak Orang Pribadi". Memiliki NPWP dan bukti pembayaran pajak selama 5 (lima) tahun terakhir yang dibuktikan dengan Surat Pemberitahuan Tahunan Pajak Penghasilan Wajib Pajak Orang Pribadi dimaksudkan untuk

${ }^{30}$ Al-Tabrizi, Misykat Al-Mashabi, (Mesir: Mansurat al-Maktab al-Islamy. T.th.), hlm. 176.

${ }^{31}$ Ibid., hlm. 128. 
mengetahui kekayaan dan ketaatannya terhadap pemertintah dalam hal mmbayar pajak. ${ }^{32}$

Syarat kedua belas "belum pernah menjabat sebagai Presiden atau Wakil Presiden selama 2 (dua) kali masa jabatan dalam jabatan yang sama". Tujuan dari syarat ini sangat baik untuk kemajuan sebuah Negara, yaitu agar kemajuan yang dicapai terus meningkat dan agar kekuasaan tidak hanya berada pada segelintir orang, tapi berputar antara individu-individu yang berkualitas dalam setiap generasi. Syarat ini sangat relevan dengan kehendk Syaari (Allah SWT.) sebagaimana dalam firman-Nya:

"Jika kamu (pada perang Uhud) mendapat luka, maka sesungguhnya kaum (kafir) itupun (pada perang Badar) mendapat luka yang serupa. Dan masa (kejayaan dan kehancuran) itu Kami pergilirkan diantara manusia (agar mereka mendapat pelajaran); dan supaya Allah membedakan orang-orang yang beriman (dengan orang-orang kafir) supaya sebagian kamu dijadikanNya (gugur sebagai) syuhada'. Dan Allah tidak menyukai orang-orang yang zhalim". (QS. Ali'Imran, 3:140). ${ }^{33}$

Syarat ketiga belas "setia kepada Pancasila sebagai dasar negara, Undang-Undang Dasar Negara Republik Indonesia Tahun 1945, dan cita-cita Proklamasi 17 Agustus 1945". Pancasila adalah falsafah bangsa Indonesia yang dirumuskan oleh tokoh-tokoh Muslim pendiri Negara Kesatuan Republik Indonesia yang memperhatikan kepentingan warga negara yang berasal dari agama lain. Ajaran Islam dikemas dalam falsafah dan dasar Negara yang bernama Pancasila.Seluruh sila-sila dari Pancasila pada dasarnya adalah ajaran Islam terkait dengan kehidupan berbangsa dan bernegara. Oleh karena itu kesetiaan terhadap Pancasila sama dengan kesetiaan terhadap ajaran Islam. ${ }^{34}$

Syarat keempat belas "tidak pernah dijatuhi pidana penjara berdasarkan putusan pengadilan yang telah mempunyai kekuatan hukum tetap karena melakukan tindak pidana yang diancam dengan pidana penjara 5 (lima) tahun atau lebih". Syarat ini merupakan syarat yang sangat dijunjung oleh ajaran Islam, karena menyangkut akhlak seseorang. Siapa pun yang

\footnotetext{
${ }^{32}$ Ibid., hlm. 67.

${ }^{33}$ Ibid., hlm. 99.

${ }^{34}$ Ibid., hlm. 93.
} 
pernah dijatuhi hukuman penjara selama lebih dari 5 tahun berarti telah melakukan perbuatan tercela; sedangkan pemimpin harus berakhlak mulia. ${ }^{35}$

Syarat kelima belas "berusia sekurang-kurangnya 35 (tiga puluh lima) tahun". Manurut para ahli psikologi usia 35 tahun itu adalah usia yang sudah mendekati pada kematangan. Penentuan usia 35 tahun sebagai syarat bagi seorang pemimpin meskipun Islam tidak menentukan seperti itu, tapi cukup Islami karena melihat fakta sejarah para pemimpim dalam Islam lebih banyak yang mulai memimpin pada usia lebih tua dari 35 tahun, sebagaimana Nabi sendiri pada usia 40 tahun. ${ }^{36}$

Syarat keenam belas "berpendidikan paling rendah tamat Sekolah Menengah Atas (SMA), Madrasah Aliyah (MA), Sekolah Menengah Kejuruan (SMK), Madrasah Aliyah Kejuruan (MAK), atau bentuk lain yang sederajat". Di Indonesia, rata-rata pencapaian pendidikan warga Negara belum sampai pada tamat SLA, oleh karena itu syarat SLA sudah berada di atas rata-rata. Calon kepala Negara menurut Islam harus memliki pengetahuan yang luas.

Syarat ketujuh belas "bukan bekas anggota organisasi terlarang Partai Komunis Indonesia, termasuk organisasi massanya, atau bukan orang yang terlibat langsung dalam G.30.S/PKI". Partai Komunis Indonesia merupakan partai terlarang di Indonesia karena ajarannya bertentangan dengan ajaran Islam. Sangat jelas syarat ini diajukan oleh para tokoh Muslim supaya Negara ini dipimpin oleh individu yang bertqwa kepada Allah SWT.QS. Al-Nisa: 141144 .

Syarat kedelapan belas "Memiliki visi, misi, dan program dalam melaksanakan pemerintahan negara Republik Indonesia". Memiliki visi, misi, dan program merupakan syarat yang harus dimiliki oleh seorang calon kepala Negara menurut Islam. Syarat untuk menjadi calon kepala Negara menuru Islam sangat ketat untuk memberikan persyaratannya salah satunya seperti yang disyaratkan oleh ahli hukum Islam yang sangat terkenal dan mumpuni dibidangnya seperti yang disampaikan oleh ulama besar Imam Al-Mawardi dalam kitab nya Al-Ahkam al-Sulthaniyah ${ }^{37}$

${ }^{35}$ Al-Tabrizi, Misykat Al-Mashabi, (Mesir: Mansurat al-Maktab al-Islamy. T.th.), hlm. 176.

${ }^{36} \mathrm{Ibnu}$ Khaldun, Muqaddimah ..., hlm. 66.

${ }^{37} \mathrm{Abu}$ al-Hasan Ali bin Muhammad bin Habib al-Basri Al-Baghdadi Al-Mawardi alSyafi'i. Al-Ahkam al-Sulthaniyyah ..., hlm. 6. 


\section{Penutup}

Berdasarkan pembahasan mengenai kritik hukum Islam terhadap Undang-undang No. 42 Tahun 2008 tentang Pemilihan Umum Presiden dan Wakil Presiden, maka dapat ditarik kesimpulan sebagai berikut: Pertama, Pemilihan presiden dan wakil presiden menurut hukum Islam adalah dengan menggunakan beberapa mekanisme yang telah dicontohkan dalam pemilihan para Khulafa al-Rasyidin di Madinah. Perbedaan mekanisme pemilihan dapat difahami sebagai dinamika cara pemilihan kepala Negara dalam Islam yang akan terus berlangsung sesuai perguliran waktu, situasi, dan kondisi.

Kedua, Pemilihan presiden dan wakil presiden di Indonesia telah mengalami perubahan yang cukup signifikan. Pada masa Orde Lama dan Orde Baru pemilihan presiden dan wakilnya dilakukan oleh anggota MPR. Sedangkan sejak Era Reformasi sampai sekarang pemilihan presiden dan wakilnya dilakukan secara langsung oleh rakyat.

Ketiga, Sistem pemilihan presiden dan wakil presiden dan syaratsyarat calon presiden dan wakil presiden di Indonesia sebagaimana diuraikandalam Undang-Undang Nomor 42 Tahun 2008 tentang Pemilihan Umum Presiden dan Wakil Presidensudah sesuai dengan hukum Islam. Bahkan, menurut penulis syarat-syarat calon presiden dan wakil presiden yang terdapat dalam Undang-Undang Nomor 42 Tahun 2008 itu bukan hanya sesuai, tapi diadopsi dari ajaran Islam yang bersumber dari Alquran dan AlSunnah.

\section{Pustaka Acuan:}

Al-Aamidi, Al-Ihkâm fi Ushûlil Ahkâm, Juz 2.

Al-Amidi, Al-Fashl fil Milal wal Ahwâ wan Nihal, Juz 4.

Al-'Asqalani, Ahmad bin 'Ali bin Hajar. t.th. Fathu al-Baariy bi Syarhi Shahihi alBukhariy. Beirut: Dar al-Ma'rifah.

Al-Haitsami, Majmau' az Zawâid, Juz 5.

Al-Mawardi, Abu Al-Hasan Ali bin Muhammad bin Habib al-Basri AlBaghdadi Al-Syafi'i, Al-Ahkam al-Sulthaniyyah wa al-Wilayah al-Diniyyah, Mesir: Dar al-Fikr, 1960 M./ 1380 H. 
Al-Mawardi, Abu al-Hasan Ali bin Muhammad bin Habib al-Basri AlBaghdadi al-Syafi'I, 1960 M./ 1380 H. Al-Ahkam al-Sulthaniyyah wa alWilayah al-Diniyyah. Cet. ke-1. Mesir: Dar al-Fikr.

Al-Mawardi, Imam, Al-Ahkam As-Sulthaniyyah, Jakarta: Gema Insani Press. 1996.

Al-Nabhani, Taqiyuddin, 1997. Nizhamul Hukmi fil Islam (Sistem Pemerintahan Islam). Bangil: Al-Izzah.

Al-Raghib al-Asfahani, Mu'jam Mufradat li Alfazh al-Qur'an, Beirut-Libanon: Dar al-Kutub al-'Ilmiyah. 2004.

Al-Tabrizi, Misykat Al-Mashabi, Mesir: Mansurat al-Maktab al-Islamy. T.th.

Amos, Abraham, Sistem Ketata Negaraan Indonesia, Jakarta: Rajawali Pers. 2007.

Anonimous. 2001. Undang-Undang Dasar Negara Republik Indonesia 1945. Hasil Amandemen 1-4. Jakarta: Penerbit Palito Media.

Anonimous. 2008. Undang-Undang Nomor 42 Tahun 2008 tentang Pemilihan Umum Presiden dan Wakil Presiden.

As-Sarkhasy, Muntaha as Sûl fi ilmil Ushul ...,Juz 1.

Budiharjo, Miriam, Pengantar Ilmu Politik, Jakarta: Gramedia Pustaka. 2000.

Clifford Geertz. The Religion of Java, Chicago: Chicago Press. 1976.

Hanbal, Ahmad bin. T.th. Musnad Ahmad bin Hanbal wa bi Hamisyihi Muntakhab Kanzul Ummal fi al-Aqwal wa al-Af'al. Beirut: Dar al-Fikr.

Huda, Ni'matul, Hukum Tata Negara, Jakarta, Rajagrafindo, 2010.

Ibn Khaldun, Abd al-Rahman. 1284 H. Muqaddimah yaitu Jilid I dari Kitab Al'Ibar wa al-Diwan al-Mubtada' wa al-Khabar. Baghdad: Al-Mutsanna. $1284 \mathrm{H}$.

Ibnu Manzhur, Lisaan al-Arab, Kairo: Daarul Ma'arif. T.th.

Moh. Mahfud MD. Demokrasi dan Konstitusi Indonesia,Jakarta. Rineka Cipta 2003.

Sjamsuddin, et.al. dalam Pribadi Toto, dkk. Sistem Politik Indonesia, Jakarta: Penerbit Universitas Terbuka, 2007, Cet. ke-2. 
Soenarjo dkk. 1986, Al-Qur'an dan Terjemahnya. Jakarta: Yayasan Penyelenggara Penterjemah/Pentafsir Al-Qur'an, Departemen Agama RI.

Suny, Ismail, Pergeseran Kekuasaan Eksekutif, Jakarta, Aksara Baru, 1983.

Tamrin, Abu, "Urgensi Pemilu Presiden dan Wakil Presiden Secara Langsung di Era Reformasi" Jurnal Cita Hukum [Online], Volume 1 Number 2 (2 December 2013).

UU No. 12 Tahun 2003 tentang Pemilihan Umum. Lihat UU No. 10 Tahun 2008 Tentang Pemilu Anggota DPR, DPD, dan DPRD. 